\title{
PEMANFAATAN UV-C CHAMBER SEBAGAI DISINFEKTAN ALAT PELINDUNG DIRI UNTUK PENCEGAHAN PENYEBARAN VIRUS CORONA
}

\section{UTILIZATION OF UV-C CHAMBER AS DISINFECTANT FOR SELF PROTECTION TOOL TO PREVENT CORONA VIRUS SPREAD}

\author{
Cahyo Mustiko Okta Muvianto ${ }^{1)}$, Kurniawan Yuniarto2)* \\ 1)Jurusan Teknik Elektro, Universitas Mataram \\ 2)Program Studi Teknik Pertanian, Universitas Mataram \\ Jalan Majapahit, Nomor 62, Kota Mataram, Provinsi NTB, 83115 \\ ${ }^{*}$ Alamat korespondensi: kurniawan2006@unram.ac.id \\ (Tanggal Submission: 20 April 2020, Tanggal Accepted: 30 April 2020)
}

\begin{abstract}
ABSTRAK
Penyebaran virus corona tidak hanya terjadi pada interaksi antara penderita (human to human), namun juga dapat menyebar melalui piranti yang digunakan oleh tenaga medis atau biasa disebut alat pelindung diri (APD). Penggunaan kembali APD boleh dilakukan apabila sudah di lakukan tahapan disinfektan sehingga dukungan alat untuk disinfektan APD sangat diperlukan bagi tenaga medis yang menangani virus Corona. Kegiatan pengabdian ini bertujuan untuk memberikan informasi langkahlangkah dalam pembuatan disinfektan alat penglindung diri dalam penanganan virus Corona berbasis iradiasi sinar UV-C. Pelaksanaan kegiatan ini meliputi: desain dan pembuatan fisik prototype disinfektan UV-C chamber; petunjuk penggunaan dan penyerahan prototype disinfektan ke rumah sakit Unram. Prototype disinfektan UV-C chamber ini memiliki dimensi 1000×1000×2000 mm dan didukung lampu UV$C$ dengan daya sebesar $200 \mathrm{~W}$. Untuk keperluan disinfektan APD dimana inti DNA virus corona akan hancur apabila terkena paparan iradiasi UV-C sebesar $67 \mathrm{~J} / \mathrm{m}^{2}$ maka operasional penyinaran APD dapat dilakukan selama minimal 15 menit. Saat ini, disinfektan UV-C chamber telah dimanfaatkan untuk disinfektan virus corona masker N-95 di Rumah Sakit Unram.
\end{abstract}

Kata Kunci: corona virus, covid-19, disinfektan, UV-C

\section{PENDAHULUAN}

Wabah corona akibat dari virus SARS-Cov2 telah menyebar ke seluruh dunia. Penyebaran di Indonesia sendiri sudah terdeteksi sejak Februari 2019 yang disebabkan oleh aktivitas pertemuan dansa dimana salah satu peserta warga negara Jepang ternyata sebagai pembawa virus. Penyebaran virus corona di duga pertama kali terjadi pada pasar hasil laut dan dilanjutkan dengan kontak antar manusia. Selanjutnya, kasus infeksi semakin tinggi ketika orang sehat berkunjung ke pasar hewan liar di Wuhan (Adhikari et al., 2020).

Secara umum, gejala yang ditimbulkan dari infeksi virus corona adalah demam, batuk dan sulit bernafas (Yuliana, 2020). Selain itu, gejala yang muncul akibat dari infeksi corona adalah batukbatuk, demam dan diikuti dengan mual, diare dan gejala pada sistem pencernaan (Nadeem, 2020). Namun, dari penyebaran yang terjadi di seluruh dunia juga timbul gejala lain dari infeksi virus corona seperti: munculnya ruam-ruam pada kulit, 
nyeri otot, batuk berdahak, mata merah dan berair, kelelahan.

Corona virus dapat menyebar melalui berbagai media. Manusia sebagai salah satu sumber transmisi penyebaran virus utama melalui tetesan atau butiran partikel akibat batuk atau bersin. Selain itu, media lain seperti logam, kertas, kaca bisa menjadi tempat untuk transmisi virus corona. Namun, berdasarkan sifatnya corona virus sensitif terhadap panas, cairan disinfektan mengandung klorin dan pelarut lemak dengan suhu $560 \mathrm{C}$ selama 30 menit, eter, alkohol, asam perioksiasetat, formalin, agen pengoksidasi dan klorofom (Wang et al., 2019).

Untuk itu, banyak disinfektan berbasis semprot di terapkan pada aktivitas pencegahan virus corona. Penggunaan disinfektan yang disemprotkan ke manusia atau lingkungan yang berpotensi menjadi transmisi virus cukup populer selama wabah corona. Namun, keberlanjutan penggunaan disinfektan semprot mendapat larangan oleh kementerian Kesehatan RI terkait dengan beberapa aspek ancaman kesehatan manusia terutama bahaya terhadap kulit dan selaput lendir. Meskipun dapat menimbulkan bahaya, penggunaan disinfektan juga masih diperbolehkan untuk penggunaannya pada alat pelindung diri (APD).

Saat ini, tim penanganan wabah corona di rumah sakit sangat bergantung kepada APD untuk melindungi dari potensi terinfeksi virus corona. Penggunaan berulang APD dilakukan karena keterbatasan rantai ketersediaan APD baru sehingga pencucian dengan klorin sangat umum di lakukan dalam mematikan keberadaan virus corona yang mungkin menempel di permukaan atau masuk ke pori dari APD. Namun, jenis APD tertentu sangat riskan rusak oleh perlakuan pencucian berulang, sehingga upaya disinfektan APD dapat di lakukan dengan metode lain.

Sinar ultraviolet (UV) dapat berfungsi sebagai agen germicidal. Paparan sinar UV jenis $C$ dengan panjang gelombang dibawah $260 \mathrm{~nm}$ dapat berfungsi untuk membunuh agen biologis seperti mikroba dan virus (Gutiérrez et al., 2015). Sebagai tambahan, paparan sinar UV-C dapat menembus ke bagian pori dari bahan APD selain efeltif untuk memberikan efek iradiasi pada permukaan bahan APD.
Berdasarkan nilai guna dari sinar UV-C sebagai agen germicial, maka perlu dikenalkan metode disinfektan virus corona untuk APD ddegan iradiasi UV-C. Tulisan ini bertujuan untuk memberikan informasi terkait metode teknis pembuatan ruang disinfektan menggunakan iradiasi UVC.

\section{METODE KEGIATAN}

Kegiaatan ini di lakukan selama selama 2 minggu yakni mulai pada tanggal 22 Maret 2020 sampai dengan 8 April 2020 di Lombok Barat, NTB.

\section{Alat dan Bahan}

Alat yang digunakan dalam pembuatan UV$C$ disinfektan chamber adalah : las listrik, gerinda potong, gergaji mesin untuk kayu, martil, bor dan "screw driver". Bahan yang dibutuhkan terdiri atas: lampu UV-C chamber produk Jepang dengan panjang gelombang $256 \mathrm{~nm}$ dan daya listrik 40 watt, kabel, stop kontak, triplek, lembaran alumunium, mur-baut, kain gordyn dan pipa besi kotak

\section{Prosedur Kerja Pembuatan UV-C disinfektan Chamber}

Prosedur pelaksanaan pembuatan UV-C disnfektan chamber terdiri atas 2 (dua) rangkaian kerja. Tahap satu, perancangan teknis UV-C disinfektan chamber melalui gambar kerja menggunakan "software solidworks" yang berfungsi untuk membuat gambar teknis prototype disinfektan UV-C chamber (Gambar 1). Tahap dua, membuat model fisik UV-C disinfektan chamber.

\section{Uji coba UV-C disinfektan chamber}

Model fisik yang telah dihasilkan dilakukan uji kerja fisik dengan diikuti prosedur pengoperasian yang aman. Pengoperasian aman diperoleh apabila benda/objek yang dicurigai terpapar oleh virus corona dikenai iradiasi sebesar $67 \mathrm{~J} / \mathrm{m} 2$. Untuk mendapatkan nilai dosis iradiasi tersebut, maka diperlukan iradiasi sebesar 60 detik untuk objek APD yang paling dekat dengan lampu UV-C dan akan semakin lama untuk objek APD yang jauh dari paparan. Rumah sakit lain seperti RSP UGM menggunakan rentang waktu sebesar 20 menit dengan daya kurang dari $200 \mathrm{~W}$, sedangkan 
dengan daya prototype yang dibuat ini dapat digunakan dengan waktu lebih pendek selama 15 menit atau untuk memastikan keamanan yang lebih dapat dilakukan iradiasi di atas 20 menit. Selain itu, untuk menjaga keamanan pengguna, wajib menghindari kontak langsung dengan lampu UV-C ubtuk melindungi bahaya yang ditimbulkan terhadap kulit dan mata.

Selanjutnya, prototype disinfektan UV-C chamber ini disumbangkan ke Rumah Sakit UNRAM untuk dimanfaatkan sebagai unit proses dalam disinfektan APD seperti masker N-95. Hal ini untuk membantu keamanan APD atau masker N-95 dapat dipakai berulang karena permasalahan stok dan untuk menjamin steril terhadap keberadaan virus Corona yang menempel pada APD.

\section{HASIL DAN PEMBAHASAN}

Program ini telah dilaksanakan secara terstruktur dengan melibatkan masyarakat secara aktif.

\section{Perancangan UV-C disinfektan chamber}
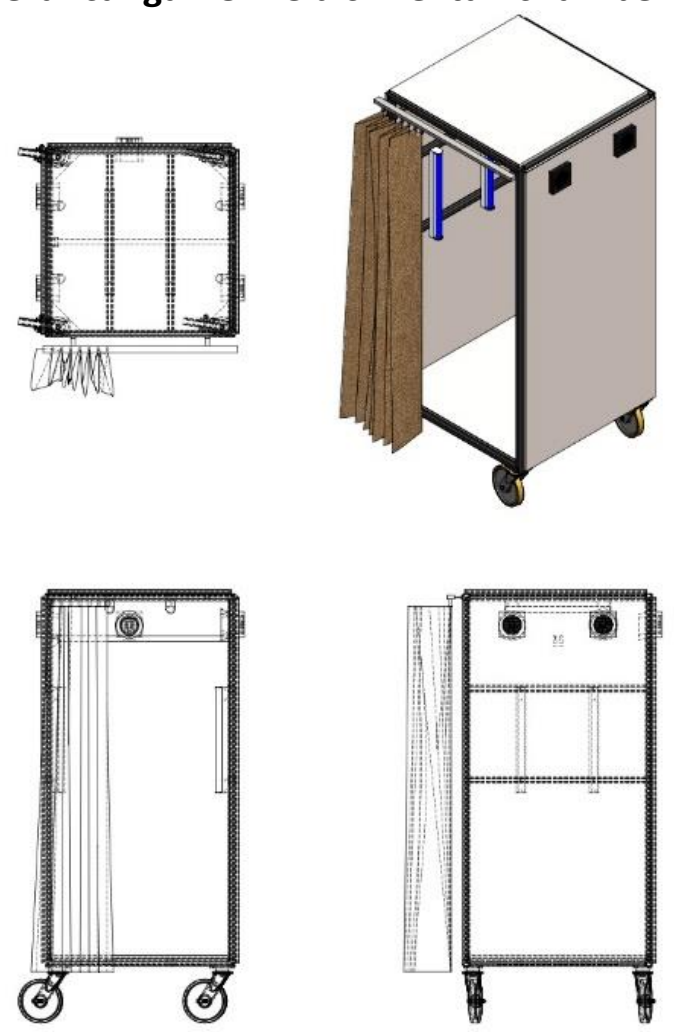

Gambar 1. Gambar teknis UV-C disinfektan chamber.
UV-C disinfektan chamber berbentuk bilik dengan dimensi (panjang $\mathrm{x}$ lebar $\mathrm{x}$ tinggi) adalah $1000 \times 1000 \times 2000$ mm. Rancangan bilik disinfektan APD di lengkapi dengan lampu UV-C germicidal sebanyak 5 (lima) buah dengan penempatan di sisi atas dan sisi samping. Berikut ini detail rancangan UV-C disinfektran chamber.

UV-C disinfektan chamber terdiri atas komponen utama berupa: rangka besi pipa kotak, dinding, roda dan lampu UV-C. Rancangan peletakan lampu UV-C chamber pada bagian atas dan samping untuk memberikan pengaruh paparan sinar UV-C yang merata ke seluruh ruangan atau sisi-sisi dari benda-benda yang akan di lakukan disinfektasi.

Penambahan unit motor penghisap udara berfungsi untuk membuang partikel yang terbentuk selama atau setelah disinfektan. Selain itu, penggunaan motor penghisap juga berfungsi mendinginkan benda-benda setelah di lakukan disinfektan sehingga dapat segera langsung di kenakan bagi tenaga medis atau paramedis.

Rancangan UV-C disinfektan chamber ini juga menggunakan konsep knock-down. Hal ini untuk memudahkan dalam proses pengangkutan datau pemindahan. Selain itu, penambahan roda untuk meringankan beban dorong atau tarik apabila dilakukan pemindahan UV-C disinfektan chamber ke area lain.

\section{Pembuatan UV-C disinfektan chamber}

Tahapan pembuatan fisik disinfektan UV-C chamber berdasarkan dari rancangan gambar teknis di serahkan kepada bengkel las. Secara umum, pembuatan rangka disinfektan UV-C chamber ini sangat mudah dikerjakan tanpa ada pelatihan khusus kecuali keahlian dalam pengelasan dan pemotongan pipa besi. Berikut ini tahapan dalam pembuatan disinfektan UV-C chamber. 


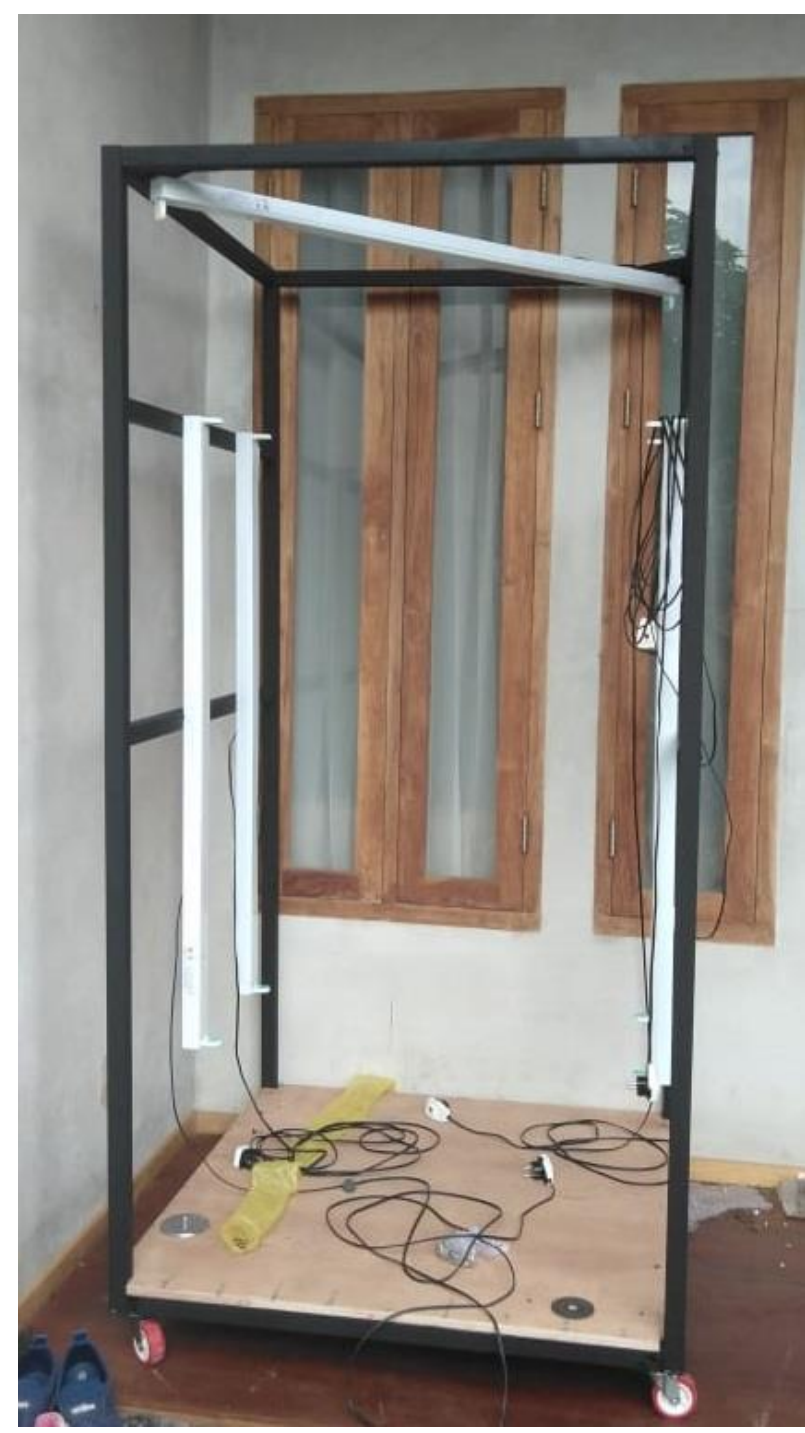

Gambar 2. Rangka UV-C chamber

Rangka disinfektan UV-C chamber terbuat dari besi pipa kotak ukuran $40 \times 40 \mathrm{~mm}$. Setiap ujung pertemuan dari sisi rangka di berikan kaitan yang memungkinkan untuk konsep knowck-down. Bagian rangka ini di sisipkan rangka tambahan untuk pegangan rumah lampu UV-C. Jumlah lampu untuk rancangan ini sebanyak 5 (lima) dengan total daya lampu sebesar 200 watt.

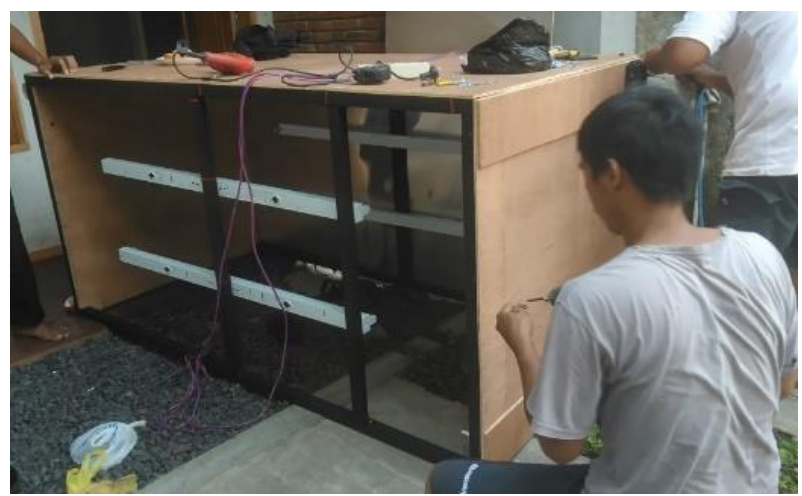

Gambar 3. Penutupan rangka

Rangka di tutup setiap sisinya menggunakan papan lapis atau triplek dengan ketebalam $9 \mathrm{~mm}$. Bagian dalam triplek di lapisi dengan logam alumunium lembaran yang dikaitkan dengan paku triplek. Fungsi dari alumunim adalam memantulkan paparan iradiasi UV-C sehingga gelombang sinarnya tidak bocor dari bilik atau chamber.

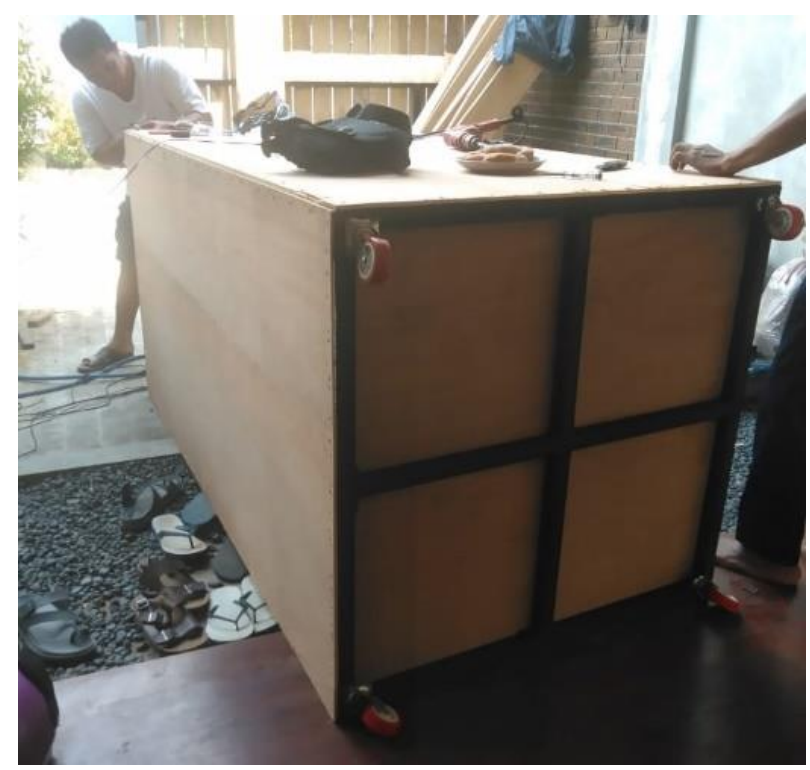

Gambar 4. Instalasi kelistrikan

Sumber iradiasi UV-C terdiri atas 5 (lima) buah lampu. Untuk memudahkan pengoperasiannya, setiap lampu yang ada di paralel menjadi satu masukan stop kontak. Kabel stop kontak sebaiknya menggunakan panjang 5000 $\mathrm{mm}$ dan diganti dengan kualitas kabel yang lebih baik. 


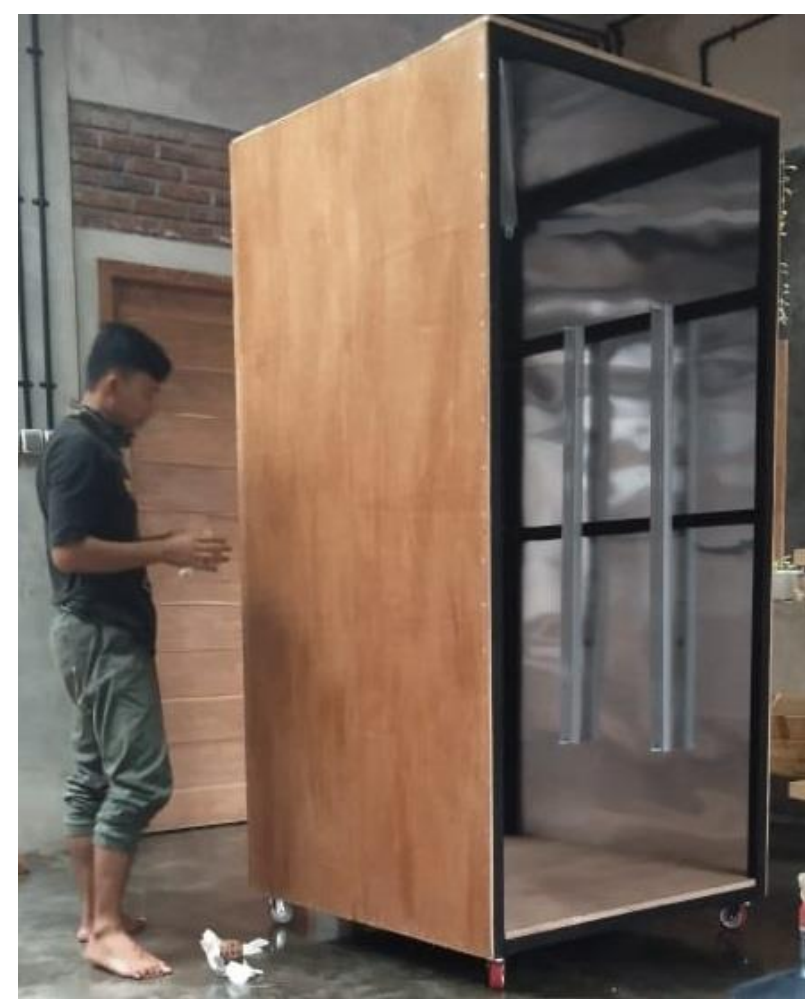

Gambar 5. Finishing dinding

Meningkatkan estetika disinfektan UV-C chamber perlu diberikan sentuhan pelitur apabila sudah terangkai semua. Untuk bagian depan, di tutup menggunakan kain gordyn yang berbahan tebal dengan dimensi (lebar $x$ tinggi) adalah $1000 x$ $2000 \mathrm{~mm}$. Penggunaan tutup gordyn sebagai akses untuk operasional disinfektan APD. Namun, untuk tingkat keamanan yang lebih baik, pintu akses yang berbahan kain gordyn dapat digantikan dengan dengan bahan seperti dinding yaitu pintu triplek yang dilapisi alumunium.

Biaya yang timbul dari pembuatan disinfektan UV-C chamber sebesar Rp 7.000.000. Nilai ini sebagai alat untuk disinfektan APD jauh lebih ekonomis dibandingkan menggunakan metode semprot maupun metode cuci.

\section{Pengoperasian dan Nilai Fungsi}

Cara mengoperasikan disinfektan UV-C chamber sebenarnya sangat mudah. Bahan APD di masukkan dan di atur ke dalam bilik, selanjutnya tutup tirai gordyn sampai rapat. Lampu UV-C dinyalakan dengan menekan stop kontak ke sumber arus.
Berdasarkan dari hasil penelusuran, bahwa jenis virus SARS-Cov-2 yang menyebabkan virus corona dapat mengalami inaktivasi dengan rusaknya bagian inti DNA apabila terpapar sinar UV-C dengan dosis sebesar $67 \mathrm{~J} / \mathrm{m} 2$. Lampu sinar UV-C dapat menegluarkan sebesar $30 \%$ dari daya lampu yang tertulis sehingga apabila menggunakan lampu $200 \mathrm{~W}$ akan sebanding dengan paparan UV$\mathrm{C}$ murni sebesar $60 \mathrm{~W}$.

Intensitas instalasi rancangan disinfektan UV-C chamber dengan suplai daya $200 \mathrm{~W}$ sebesar $1.25 \mathrm{~J} / \mathrm{m} 2$. Secara teoritis, untuk menndapatkan dosis sebesar $67 \mathrm{~J} / \mathrm{m} 2$ dapat di lakukan selama kurang dari 60 detik atau 54 detik. Namun, untuk keperluan keamanan maka proses untuk tujuan disinfektan, dapat dilakukan lebih dari waktu teoritis. Secara umum, banyak rumah sakit menggunakan fungsi disinfektan selama 15-20 menit sehingga kami merekomendasikan selama 20 menit untuk lama penyinarannya.

\section{Aplikasi dan Penggunaanya}

Hasil prototype disinfektan UV-C chamber ini bertujuan untuk upaya sterilisasi kering dari APD terhadap penyebaran virus corona. Sesuai dengan target penggunanya pengguna APD maka diperuntukkan di rumah sakit.

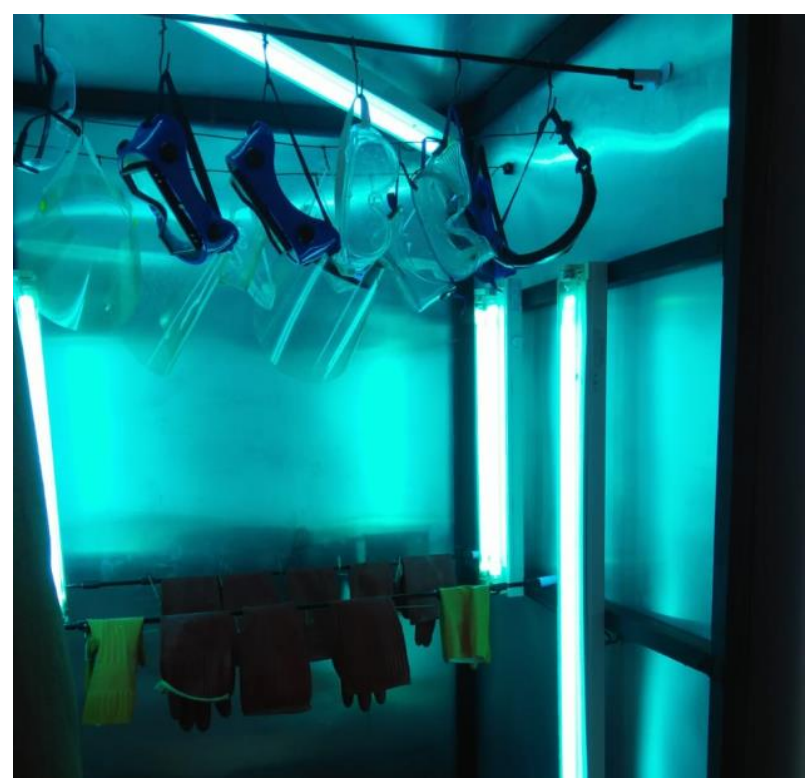

Gambar 6. Penggunaan UV-C Chamber untuk disinfeksi alat peilndung diri (kaca mata dan sarun tangan) 
Rumah Sakit Unram

$13 \mathrm{hrs} \cdot \mathrm{a}$

Hari ini RS Unram berbangga menerima sumbangan sterilizator alat berbasis UVGI (ultraviolet-C Germicidal) dari dosen Univeristas Mataram.

Cahyo Mustiko Okta Muvianto, PhD dari FT Unram dan

Dr. Kurniawan Yuniarto Fatepa

Adapun kegunaaannya utk sterilisasi N95, Hazmat, Boot, google dan faceshield. Terimakasih pak Dr Cahyo dan pak Dr Wawan

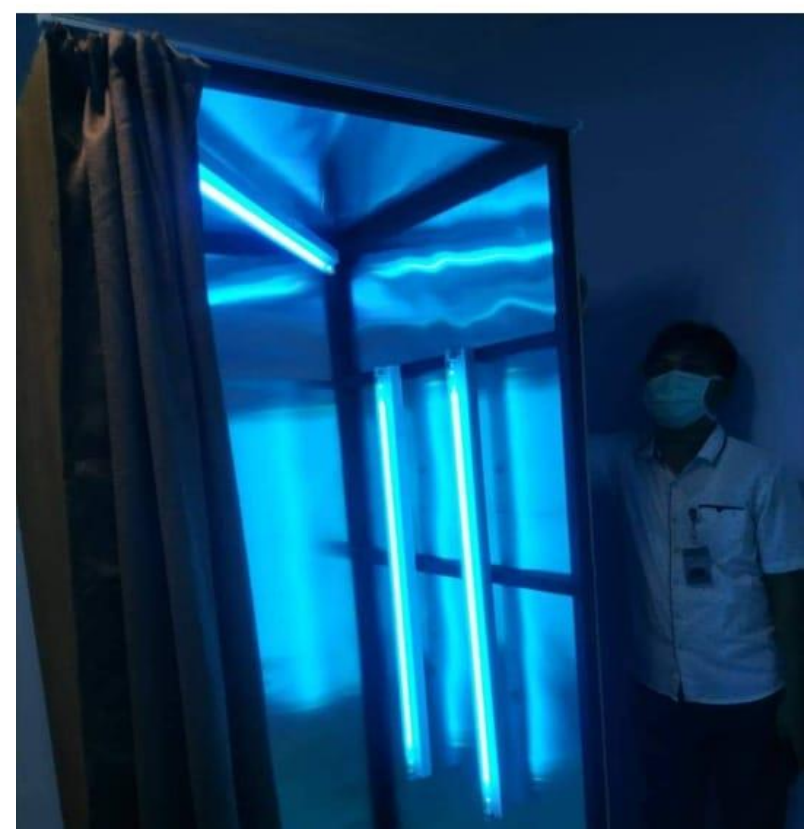

Gambar 7. Testimoni dari Pengguna UV-C chamber, melalui akun media sosial facebook

Saat ini, disinfektan UV-C chamber telah dimanfaatkan untuk sterilisasi N-95 atau masker yang biasa dipakai tenaga medis dan paramedis. Rumah Sakit Unram telah merasakan faedah dari pemanfaatan alat ini, karena apabila dengan sterilisasi basah justru akan cepat merusak masker atau APD lainnya.

Sebagai pelengkap dalam kegiatan operasional, pemahaman akan bahaya yang timbul dari paparan UV-C adalah kontak langsung dengan kulit dan mata. Operator harus melindungi diri dari kontak langsung terhadap paparan sinar UV-C sehingga dalam pengoperasiannya cukup menyalakan lampu dan mematikan lampu tanpa perlu melakukan aktivitas di sekitar UV-C chamber.

\section{KESIMPULAN}

Disinfektan UV-C chamber dapat dibuat dengan mudah dan berbiaya rendah. Fungsi utama dari UV-C chamber ini adalah untuk disinfektan APD pengganti disinfektan semprot atau cuci. Efisien proses disinfektan dan fungsi UV-C sebagai germicidal dapat diberikan ke APD dengan lama paparan tidak kurang dari 15 menit.

\section{UCAPAN TERIMA KASIH}

Kegiatan ini terselenggara atas pendanaan pribadi tim penulis. Kami ucapkan terimakasih kepada seluruh pihak yang terlibat pada kegiatan pengabdian kepada masyarakat ini.

\section{DAFTAR PUSTAKA}

Adhikari, S.P., Meng, S., Wu, Y., Mao, Y., Ye, R., Wang, Q., Sun, C., et al. (2020), "Epidemiology , causes, clinical manifestation and diagnosis , prevention and control of coronavirus disease ( COVID-19) during the early outbreak period: a scoping review", Infectious Diseases of Poverty, Vol. 9 No. 29, pp. 1-12.

Gutiérrez, D.R., Char, C., Escalona, V.H., Chaves, A.R. and Rodríguez, S.D.E.L.C. (2015), "Application of UV-C Radiation in the conservation of minimally processed rocket ( Eruca Sativa Mill.)", Food Processing and Preservation, Vol. 39, pp. 3117-3127.

Nadeem, S. (2020), "Coronavirus Covid-19: Avalaibel Free Literature Provided By Various Companies, Journals and Organizations Around the World", Journal of Ongoing Chemical Research, Vol. 5 No. 1, pp. 7-13.

Yuliana. (2020), "Wellness and healthy magazine", Wellness and Healthy Magazine, Vol. 2 No. February, pp. 187-192. 